[RAdiocarbon, Vol. 11, No. 2, 1969, P. 345-350]

\title{
GIF NATURAL RADIOCARBON MEASUREMENTS IV
}

\section{G. DELIBRIAS, S. M. NAKHLA, and J. LABEYRIE}

Centre des Faibles Radioactivités, Centre National de la

Recherche Scientifique 91, Gif-sur-Yvette, France

This list reports certain measurements made from 1965 to 1967. These samples are devoted to a special study of organic matter in soils. The work in large part is the subject of a thesis defended in Paris by S. M. Nakhla, 1968.

\section{SAMPLE DESGRIPTIONS}

\section{Bomb $C^{14}$ in soils}

A series of $\mathrm{C}^{14}$ measurements were made on different types of soils in France, to study the geochemical evolution of chemically different fractions of organic matter. $\mathrm{C}^{14}$ enrichment, in per cent, from nuclear tests, has been measured for three years from 1964, in organic fractions of different types of soils in France, as function of depth. The fractions of interest are:

1) plant residues,

2) humic acids, the fraction of soil organic matter soluble in alkaline solutions and precipitable by concentrated $\mathrm{H}_{2} \mathrm{SO}_{4}$,

3) humins, the fraction insoluble in alkaline solutions.

\section{Gif-sur-Yvette, Essonne, series}

Samples coll. each year, in August, since 1964, in forest sandy soil $(\mathrm{pH} 4.5)$, covered with chestnuts and oak trees $\left(48^{\circ} 44^{\prime} \mathrm{N}\right.$ Lat, $2^{\circ} 14^{\prime} \mathrm{E}$ Long). Three layers are studied, 0 to $3 \mathrm{~cm}, 3$ to $9 \mathrm{~cm}, 9$ to $20 \mathrm{~cm}$ which lie on parent rock. In layer 0 to $3 \mathrm{~cm}$, plant residues, mainly leaves, are already half decomposed. Coll. and subm. by S. M. Nakhla and G. Delibrias.

Gif-502. Gif 0 to $3 \mathrm{~cm}$ depth, humic acids $1964+15 \%$

Gif-503. Gif 0 to $3 \mathrm{~cm}$ depth, humins $1964+28 \%$

Gif-504. Gif 0 to $3 \mathrm{~cm}$ depth, leaves $1964+37.5 \%$

Gif-505. Gif 3 to $9 \mathrm{~cm}$ depth, humic acids 1964 O

Gif-506. Gif 3 to $9 \mathrm{~cm}$ depth, humins $1964+9 \%$

Gif-507. Gif 3 to $9 \mathrm{~cm}$ depth, roots $1964+50.5 \%$

Gif-508. Gif 9 to $20 \mathrm{~cm}$ depth, humic acids $380 \pm 100$ 1964

A.D. 1570

Gif-509. Gif 9 to $20 \mathrm{~cm}$ depth, humins $1964+7 \%$

Gif-510. Gif 0 to $3 \mathrm{~cm}$, humic acids $1965+17.5 \%$

Gif-511. Gif 0 to $3 \mathrm{~cm}$, humins $1965+29 \%$ 
Gif-512. Gif 0 to $3 \mathrm{~cm}$, leaves 1965

$$
+62 \%
$$

0

Gif-513. Gif 3 to $9 \mathrm{~cm}$, humic acids 1965

$+12.5 \%$

Gif-514. Gif 3 to $9 \mathrm{~cm}$, humins 1965

$+58 \%$

Gif-515. Gif 3 to $9 \mathrm{~cm}$, roots 1965

$420 \pm 100$

Gif-516. Gif 9 to $20 \mathrm{~cm}$, humic acids 1965

A.D. 1530

Gif-517. Gif 9 to $20 \mathrm{~cm}$, humins 1965

Gif-530. Gif 0 to $3 \mathrm{~cm}$, leaves 1966

$$
+3.2 \%
$$

$+73.5 \%$

Gif-531. Gif 0 to $3 \mathrm{~cm}$, humins 1966

$+40 \%$

Gif-532. Gif 0 to $3 \mathrm{~cm}$, humic acids 1966

$+\mathbf{2 0 . 5} \%$

Gif-533. Gif 3 to $9 \mathrm{~cm}$, roots 1966

Gif-534. Gif 3 to $9 \mathrm{~cm}$, humins 1966

Gif-535. Gif 3 to $9 \mathrm{~cm}$, humic acids 1966

Gif-546. Gif 9 to $20 \mathrm{~cm}$, humins 1966

Gif-547. Gif 9 to $20 \mathrm{~cm}$, humic acids 1966 $+\mathbf{2 8} \%$

0

0

Comment: $\mathrm{C}^{14}$ activity is always found higher for humins than humic acids, which means humins should be younger.

\section{Belle-Viste-Le Puch, Cestas series, Gironde}

Samples were coll. in surface layers $(\mathrm{pH} 4.5)$ of podzol profile, at Belle-Viste-Le Puch, Cestas ( $41^{\circ} 25^{\prime} \mathrm{N}$ Lat, $0^{\circ} 30^{\prime} \mathrm{W}$ Long). Surrounding area is mainly covered with young pine trees and herbs; most of soil is of quartz sand. Coll. and subm. Oct. 1965 by P. Dutil, G. Delibrias, and S. M. Nakhla.

Gif-518. Belle-Viste, superficial vegetal level $+42 \%$

Gif-554. Belle-Viste, 0 to $1 \mathrm{~cm}$ depth, humins $+22 \%$

Gif-519. Belle-Viste, 0 to $1 \mathrm{~cm}$ depth, humic acids $\quad+9 \%$

Gif-520. Belle-Viste, 1 to $3 \mathrm{~cm}$ depth, humins 0

Gif-522. Belle-Viste, 1 to $3 \mathrm{~cm}$ depth, humic acids

Gif-521. Belle-Viste, 3 to $6 \mathrm{~m}$ depth, humins

Gif-522. Belle-Viste, 3 to $6 \mathrm{~cm}$ depth, humic acids 0 Comment: humins are, according to level, either same age or younger than humic acids. 


\section{Grignon series}

Upper layers of calcareous soil $(\mathrm{pH} 8)$ with natural vegetation of herbs and oak trees at Grignon, SW Versailles $\left(48^{\circ} 48^{\prime} \mathrm{N}\right.$ Lat, $2^{\circ} 08^{\prime} \mathrm{E}$ Long). Coll. and subm. June 1967 by P. Dutil, G. Delibrias, and S. M. Nakhla.

Gif-548. Grignon, surface leaves $+77 \%$

Gif-549. Grignon, underlying leaves half decomposed $+79 \%$

Gif-550. Grignon, 0 to $2 \mathrm{~cm}$ depth, humins $+60 \%$

Gif-551. Grignon, 0 to $2 \mathrm{~cm}$ depth, humic acids $+\mathbf{8 \%}$

Gif-552. Grignon, 2 to $5 \mathrm{~cm}$ depth, humins

Gif-553. Grignon, 2 to $5 \mathrm{~cm}$ depth, humic acids

General Comment: in any case, humins are either same age or younge: than humic acids. In studied soils, humic acids were oldest fraction of organic matter; humic acids are therefore most stable fraction in these soils. More details are publ. elsewhere (Nakhla and Delibrias, 1967).

\section{PODZOLS}

Podzols have been studied in different parts of France and in Belgium. For some, datings could be obtained all along profile, both for humic acids and humins, but in most cases, only $\mathrm{B}$ horizon has been dated.

\section{Fontainebleau series}

\section{A. Paris Basin}

Podzol fossilized under sand hill, $1 \mathrm{~m}$ high, in Fontainebleau forest ( $48^{\circ} 24^{\prime} \mathrm{N}$ Lat, $2^{\circ} 42^{\prime} \mathrm{E}$ Long). Formation of hill followed fire which probably burned down forest and destroyed vegetation. Coll. and subm. 1966 by S. M. Nakhla and G. Delibrias.

\section{Gif-544. Fontainebleau, $A_{0}-1$ horizon}

$2700 \pm 150$

Humic acids from $\mathrm{A}_{0}-1$ horizon, $20 \mathrm{~cm}$ thick, $1 \mathrm{~m}$ depth under hill.

\section{Gif-545. Fontainebleau, $B_{1}$ horizon}

Brown level, $20 \mathrm{~cm}$ below $\mathrm{A}_{\mathrm{o}}$ horizon.

General Comment: layer of charred remains at top of $A_{o}$ horizon has been dated 2075 B.P. (Gif-340, Gif II). Podzolization was probably stopped by fire and setting of sand hill.

\section{Rochefort-en-Yvelines series}

Podzol, at Rochefort-en-Yvelines (48 $35^{\circ} \times$ Lat, $1^{\circ} 59^{\prime}$ E Long), in forest essentially composed of oaks and chestnut trees, is fully developed and has well characterized B horizon and "lessivé" A horizon, without organic material. Coll. 1967 and subm. by G. Delibrias and S. M. Nakhla. 
Gif-560. Rochefort-en-Yvelines, 5 to $20 \mathrm{~cm}$ $490 \pm 100$

Gif-561. Rochefort-en-Yvelines, 70 to $75 \mathrm{~cm}$ A.D. 1460

$$
3450 \pm 180
$$

1500 B.C.

General Comment: date obtained for 5 to $20 \mathrm{~cm}$ level corresponds to age obtained above in this list for humic acids from lowest layer of superficial soil.

\section{Rambouillet series}

Profile with 5 superimposed levels, from $20 \mathrm{~cm}$ to $110 \mathrm{~cm}$ depth, in Rambouillet forest ( $48^{\circ} 39^{\prime} \mathrm{N}$ Lat, $1^{\circ} 50^{\prime}$ E Long). Slightly sloping site may have been eroded at surface; it is presently covered by moss and ferns with pines and oaks. Although profile is very differentiated, it is not typical podzol: humic acids were present all along profile from $A_{1-2}$ horizon to $\mathrm{B}_{2}$ horizon. Coll. and subm. by G. Delibrias and S. Nakhla.

\section{Gif-555. Rambouillet, 5 to $25 \mathrm{~cm}$ \\ Gif-556. Rambouillet, 25 to $50 \mathrm{~cm}$ \\ Gif-557. Rambouillet, 50 to $70 \mathrm{~cm}$ \\ Gif-558. Rambouillet, 70 to $90 \mathrm{~cm}$ $\mathrm{B}_{1}$ horizon of podzol.} $2250 \pm 150$ 300 B.C. $2720 \pm 150$ 770 в.c.

\section{Gif-559. Rambouillet, 90 to $110 \mathrm{~cm}$}

$\mathrm{B}_{2}$ horizon of podzol.

$$
\begin{gathered}
2710 \pm 150 \\
760 \text { B.c. } \\
2730 \pm 150 \\
780 \text { B.c. }
\end{gathered}
$$

$$
\begin{aligned}
& 2820 \pm 150 \\
& 870 \text { B.C. }
\end{aligned}
$$

General Comment: it is difficult to say if difference between ages for $\mathbf{5}$ to $25 \mathrm{~cm}$ and 70 to $90 \mathrm{~cm}$ levels indicates that profile differentiation occured in short time and that podzolization was suddenly stopped for unknown reasons or if it is a case of 2 superimposed podzols.

\section{B. Southwest region of France}

\section{Podzol of Belle-Viste-Le Puch, Cestas series, Gironde}

Sandy podzol situated under surface of soil studied from Gif-518 to Gif-523, with 2 brown B horizons; humic matter is present all along profile making dating possible. Coll. and subm. 1967 by P. Dutil, G. Delibrias, and S. M. Nakhla.

Gif-562. Belle-Viste-Le Puch, 6 to $12 \mathrm{~cm}$, humin

Gif-563. Belle-Viste-Le Puch, 6 to $12 \mathrm{~cm}$, humic acids

0\%, Modern

Gif-564. Belle-Viste-Le Puch, 12 to $30 \mathrm{~cm}$, humin

$A_{1}$ horizon of podzol.

0\%, Modern 
Gif-565. Belle-Viste-Le Puch, 12 to $30 \mathrm{~cm}$, humic acids

$1010 \pm 100$

Gif-566. Belle-Viste-Le Puch, 30 to $50 \mathrm{~cm}$, humin 0\%, Modern

$\mathrm{A}_{2}$ horizon of podzol.

Gif-567. Belle-Viste-Le Puch, 30 to $50 \mathrm{~cm}$, humic acids

$1450 \pm 120$

Gif-528. Belle-Viste-Le Puch, 50 to $70 \mathrm{~cm}$, humic acids

A.D. 500

$2440 \pm 160$

490 в.c.

$\mathbf{B}_{1}$ horizon of podzol. Comment: no more humin found at this depth.

Gif-529. Belle-Viste-Le Puch, 70 to $90 \mathrm{~cm}, \quad 2430 \pm 160$ humic acids

480 B.C.

$\mathrm{B}_{2}$ horizon of podzol.

General Comment: presence of important amounts of organic matter in $A_{1}$ and $A_{2}$ horizons and decreasing ages until $50 \mathrm{~cm}$ depth can be explained in 2 ways: either podzolization suddenly 1000 yr ago and profile was fossilized during its development or it is double-podzol and there is still migration of organic matter through profile. This 2nd solution seems most probable, because thickness of $B_{1}$ and $B_{2}$ horizons, which are both same age indicates differentiation of lst podzol occurred in short period of time.

\section{Gif-323. "La Piada", Gironde}

$2360 \pm 150$

Humic acids from B horizon, $18 \mathrm{~cm}$ thick, from well-developed podzol, $1 \mathrm{~m}$ depth in sands at "La Piada," $10 \mathrm{~km} \mathrm{SE}$ of Saint-Symphorien, Gironde (44 $26^{\prime} \mathrm{N}$ Lat, $0^{\circ} 29^{\prime} \mathrm{W}$ Long). Soil covered by pine forest and moor. Coll. and subm. 1964 by P. Dutil, Sta. Agron., Châlons-sur-Marne.

\section{Gif-324. "Le Poteau", Gironde}

Humic acids from $\mathrm{B}$ horizon, $20 \mathrm{~cm}$ thick, from well-developed podzol in Landes, at so-called "Le Poteau," $10 \mathrm{~km} \mathrm{~S}$ of Captieux $\left(44^{\circ} 15^{\prime} \mathrm{N}\right.$ Lat, $0^{\circ} 18^{\prime}$ W Long). Coll. and subm. 1964 by P. Dutil.

\section{Massif de l'Aigoual, Massif Central, France}

Profiles of podzolic soils above black level of ancient soil, in Massif de l'Aigoual, Massif Central, where basement is granite and schist, alt 1300 m. Coll. and subm .1967 by P. Lossaint, Centre d'Etudes Phytosociol. et Ecol., Montpellier, Hérault.

Lous Cougnet series, Massif de l'Aigoual

Gif-1002. Lous Cougnet, 25 to $50 \mathrm{~cm}$

(44 $07^{\prime} \mathrm{N}$ Lat, $3^{\circ} 33^{\prime}$ E Long)

Gif-1003. Lous Cougnet, 50 to $73 \mathrm{~cm}$

$2320 \pm 150$

370 в.C.

$2400 \pm 150$

450 B.C. 


\section{Gif-1004. Lous Cougnet, 73 to $85 \mathrm{~cm}$}

\section{Chemin Grand-Hôtel series, Massif de l'Aigoual}

\section{Gif-1005. Chemin Grand-Hôtel, 4 to $45 \mathrm{~cm}$ (44 $06^{\prime} \mathrm{N}$ Lat, $3^{\circ} 33^{\prime}$ E Long) \\ A.D. 410 \\ Gif-1006. Chemin Grand-Hôtel, 45 to $60 \mathrm{~cm}$ \\ $4300 \pm 250$ \\ 2350 B.c.}

$1540 \pm 120$

General Comment: according to submitter, Gif-1004 and Gif-1006 are 2 black levels anterior to formation of upper podzol. B horizons should be dated by Gif-1002 and Gif-1005. Date for Gif-1005 is not very significant because it gives mean age for too thick level $(4$ to $45 \mathrm{~cm}$ ); true age of inferior part of level is probably greater.

\section{Belgium}

\section{Gif-1140. Berlare, Flandres}

\section{$2680 \pm 150$}

B horizon from sandy podzol in pit, in sandy Flemish region, at Berlare, E of Gent (51 $1^{\circ} 1^{\prime} \mathrm{N}$ Lat, $3^{\circ} 57^{\prime} \mathrm{E}$ Long). Coll. and subm. 1967 by C. Sys, Geol. Inst., Gent.

\section{Gif-1141. Beernem, Flandres}

B horizon from sandy podzol in forest at Beernem, NW of Gent (51 $1^{\circ} 7^{\prime} \mathrm{N}$ Lat, $3^{\circ} 19^{\prime}$ E Long). Coll. and subm. 1968 by C. Sys.

General Comment for podzols: same age found for upper and lower part of thick B horizon at Belle-Viste-Le Puch (Gif-528, 529) indicates that migration of organic matter from surface occurred over very short period of time. Age of this horizon would be fairly significant to date this phenomenon. Moreover, this confirms assumption that $\mathbf{B}$ horizons are biologically inert.

According to results obtained it is possible to locate a period of strong podzolization, in studied regions of France and Belgium, between 2200 and 3450 B.P.: period well-known for cool and moist climate, favorable to development of this phenomenon. If compared to ages obtained for B horizon of podzol by Perrin et al. (1964) and Scharpenseel et al. (1968), podzols studied here seem rather older.

\section{Date lists: \\ Bonn I Scharpenscel, Pietig, and Tamers, 1968 \\ Gif II Delibrias, G., Guillier, M. T., and Labeyrie, J., 1966}

Nakhla, S. M. and Delibrias, G., 1967, Utilisation du carbone-14 d'origine thermonucléaire pour l'étude de la dynamique du carbone dans le sol: Conference on Radioactive dating and methods of low-level counting, I.A.E.A., Vienna, SM-87/7.

Nakhla, S. M., 1968, Etude du comportement du carbone organique dans le sol et étude des podzols à l'aide du carbone-14: Thesis, Fac. Sci. Orsay, Univ. de Paris.

Perrin, R. M. S., Willis, E. H., and Hodge, C. A. H., 1964, Dating of humus podzols by residual radiocarbon activity, Nature, v. 202, p. 165-166. 